\title{
Intradiscal electrothermal therapy for chronic discogenic low back pain: a comparison of two heating protocols
}

\author{
Korgün Ökmen ${ }^{1}$, Burcu Metin Ökmen² \\ ${ }^{1}$ Department of Anesthesiology and Reanimation, University of Health Sciences, Bursa Yüksek Ihtisas Training and Research Hospital, \\ Bursa, Turkey \\ ${ }^{2}$ Department of Physical Medicine and Rehabilitation, University of Health Sciences, Bursa Yüksek Ihtisas Training and Research \\ Hospital, Bursa, Turkey
}

\begin{abstract}
Objectives. This study aims to evaluate the effect of intradiscal electrothermal therapy (IDET) applied in patients with chronic low back pain using two heating protocols. Methods. In this study, data of 50 patients who were exposed to percutaneous IDET using two heating protocols were retrospectively analyzed. The patients were divided into two groups: in Group $1(\mathrm{n}=25)$, maximum $750 \mathrm{C}$ catheter tipping was used, while in Group 2 ( $\mathrm{n}=25)$, maximum 900C catheter tipping was performing. Pre-treatment (M0) and post-treatment results at 3 (M3), 6 (M6), 12 (M12), and 18 months (M18) were evaluated using the visual analogue acale (VAS), Oswestry disability index (ODI), and short form-36 (SF-36) scores. Results. There was no statistically significant difference in demografic characteristics and M0 VAS, ODI values and SF-36 dimensions of the patients between the groups $(\mathrm{p}>0.05)$. It was found that there were statistically significant improvement than baseline values in the M3, M6, M12, and M18 VAS, ODI, and SF-36 scores in both treatment groups (p < 0.05). Between the group comparison; only the M18 VAS and SF-36 pain values were found statistically significant in the positive direction in Group $2(\mathrm{p}<0.05)$. Conclusion. Similar successful results were obtained in our study involving two different heating procedures up to 12 months of administering IDET treatment. But at the 18 th month the $900 \mathrm{C}$ IDET seems to be more effective in improving the pain scores.
\end{abstract}

Keywords: chronic low back pain, intradiscal electrothermal therapy, intradiscal treatment

\section{Introduction}

A herniated disc is caused when the nucleus pulposus (NP) breaches the annulus fibrosus (AF). Low back and leg pain, and lumbar disc disease (LDD) develop as a result of degenerative disc herniation [1]. On the other hand, $40 \%$ of chronic low back pain has been reported to be due to discogenic pain [1, 2]. Many treatment methods have been reported in the treatment of LDD, including medical (i.e., non-steroidal anti-inflammatory drugs), physical medicine and rehabilitation (PMR), and, if indicated, surgery and minimal invasive interventions (i.e., epidural therapy, intradiscal interventions) can be 
applied [1]. Currently, percutaneous modalities including intradiscal electrothermal therapy (IDET), light amplification by stimulated emission of radiation (LASER), radiofrequency (RF), and pulsed RF techniques are frequently in use [3-5].

Intradiscal electrothermal therapy was first used by Sall\&Sall [6] in 1997. The standard procedure is as follows: after inserting the intradiscal catheter with the flexible tip at the posterior annulus, the tip temperature is elevated from $65^{\circ} \mathrm{C}$ to $90^{\circ} \mathrm{C}$ over 12.5 minutes, and the procedure is maintained at this temperature for four minutes. The temperature of $\mathrm{AF}$ is elevated to $60^{\circ} \mathrm{C}$ to $65^{\circ} \mathrm{C}$ using this procedure. The possible mechanism for IDET involves thermocoagulation of unmyelinated nerve fibers and stabilization of collagens in the annular fracture through shrinking of nociceptors [7]. Several studies have reported the short-term (12-month) and long-term (24-month) success of this treatment modality, while some others have shown no efficacy of this procedure [8-10]. On the other hand, literature reviews and meta-analyses of meticulously selected studies among patients with positive discography and magnetic resonance imaging (MRI) findings have demonstrated that the procedure can be effective and safe $[10,11]$. Although rare, certain permanent or temporal neural injuries due to heat effect have been also reported following IDET as a minimal invasive procedure $[12,13]$.

We could not find a study comparing different catheter tip temperatures in patients who applied IDET in the literature. In this study, we aimed to evaluate the effect of IDET applied at targeted catheter tip temperatures of $75^{\circ} \mathrm{C}$ and $90^{\circ} \mathrm{C}$ in patients with chronic low back pain (CLBP) associated with LDD.

\section{Methods}

This study was planned as retrospective and controlled. The study protocol was approved by the local Ethics Committee (The decision number: 2011KAEK-25 2016/08-02). A public hospital records of a total of 260 patients who were admitted to neurosurgery, algology, and PMR outpatient clinics between January 2012 and January 2015, and who underwent percutaneous intradiscal intervention were retrospectively analyzed. Inclusion criteria were as follows: the presence of low back pain unresponsive to medical or PMR therapies for more than six months, presence of a negative straight-leg raise test, normal neurological examination findings, positive discography as assessed by higher visual analogue scale (VAS) scores ( $>50 \%$ with discography), absence of nerve root compression on lumbar MRI, less than $50 \%$ decrease in the disc height, and $\leq 3 \mathrm{~mm}$ disc protrusion with a VAS score of $>5$.

Exclusion criterias were as follows: extruded or sequestrated discs, two or more pathological discs, moderate or severe spinal stenosis, systemic infection, history of or current disc infection, surgical site infection, lower extremity radiculopathy, and systemic opioid use.

Fifty patients who met the inclusion criteria during follow-up were examined into two groups: Group 1 included the patients who underwent $75^{\circ} \mathrm{C}$ IDET $(n=25)$, and Group 2 included the patients who underwent $90^{\circ} \mathrm{C}$ IDET $(n=25)$.

The level where the procedure was to be performed in the prone position was identified with $\mathrm{C}$ arm fluoroscopy. After site preparation, local anesthesia was given. The needle in an appropriate length was, then, inserted 8 to $12 \mathrm{~cm}$ laterally in the midline at the appropriate disc level using the tunnelvision technique. The needle site was confirmed in the anteroposterior and lateral positions. The intradiscal catheter directed with $17 \mathrm{G}$ (SpineCATH ${ }^{\circledR}$ NeuroTherm, Wilmington, MA, USA) was placed in the posterior annulus of the symptomatic disc. After initiating the $65^{\circ} \mathrm{C}$ heating protocol, an increase of $1^{\circ} \mathrm{C}$ was made within 30 seconds. Approximately five minutes after the beginning of the procedure, a stable temperature of $75^{\circ} \mathrm{C}$ was achieved and the procedure was terminated at this temperature at 16 minutes. In Group 2, a temperature of $90^{\circ} \mathrm{C}$ was achieved over 12.5 minutes with a standard procedure. The procedure was terminated at this temperature at 16 minutes. $1 \mathrm{~mL}$ physiological saline + antibiotic (cefazolin) mixture was injected into the disc following the procedure. Both heating protocols were applied by the same expert investigator. The patients did not know which heating procedure they were treated. The routine controls of the patients were performed in physical therapy outpatient clinics. Before treatment (M0) and after treatment results at three (M3), six (M6), 12 (M12), and 18 months (M18) were evaluated using the VAS, Oswestry disability Index (ODI), and short form-36 (SF-36) scores by an another blind investigator who did not attempt the intradiscal electrothermal therapy in routine controls. Pain intensity was measured using 0-10 cm VAS $(0=$ no pain, $10=$ intolerable pain) [14]. ODI is used to assess the level of functional disability. It is a self- 
administered questionnaire and is consisting of 10 questions about activities of daily living scored between 0 and 5. Final result is calculated as patient's score/ maximum score $\mathrm{X} 100$. The total score is between 0 and 50 [15].

The SF-36 is also a self-administered questionnaire which gives information on positive or negative health status of the individual. This scale evaluates the eight dimensions for the past four weeks [16].

The patients were asked whether they had received any other treatment when they came for control visit and were allowed to use paracetamol for pain.

\section{Statistical Analysis}

All statistical calculations were performed by using the SPSS 22.0 program. When the study data were evaluated, the Fisher Exact test was used to compare gender and the Pearson chi square $\left(\sigma_{2}^{2}\right)$ test was used in the comparison of the qualitative variables, in addition to descriptive statistical methods (frequency, percentage, mean and standard deviation). Shapiro-Wilk test were used to assess for conformity to normal distribution. When normally distribution was found, student's t test was used for comparisons between groups. When variables were found nonnormally distributed, Mann Whitney U test was used for comparisons between groups and Wilcoxon test was used for intragroup analysis. Friedman's test was used for multiple time point comparisons. Where significant differences have been detected, LSD and Tukey's HSD tests were used to identify the time point/s responsible for such differences. Significance level was set at $p=0.05$.

\section{Results}

Of 50 patients, 20 were males and 30 were females. The median age for group 1 was 58 (range: 48 to 70) years and for group 2 was 59 (range: 36 to 70) years. When the demographic characteristics of the patients are examined, there was no statistically significant difference in terms of age, gender, body mass index (BMI), duration of disease and level of the disc between the groups $(p>0.05)$ (Table 1). Additionally, there was also no statistically significant difference between groups in M0 VAS, ODI values and SF-36 dimensions of the patients $(p>0.05)$ (Tables 2 and 3 ).

When the values of M3, M6, M12 and M18 VAS and ODI subcomponents are compared with M0 values, statistically significant improvement was found in all groups according to M0 values in both groups $(p<0.05)$ (Table 2).

Between the groups, there was no statistically significant difference in the M3, M6 and M12 VAS and SF-36 subcomponent values ( $p>0.05)$, while the M18 VAS and SF-36 pain values were found statistically significant in the positive direction in Group $2(p<0.05)$. When the values of M3, M6, M12 and M18 in ODI and SF-36 values other than pain subcomponent were compared, no statistically significant difference was found between the two groups $(p>0.05)$ (Table 3).

Three patients in Group 2 reported pain-related discomfort during the procedure, however, pain was

Table 1. Comparison of the demographic characteristics of the patients.

\begin{tabular}{lccc}
\hline & $\begin{array}{c}\text { Group 1 } \\
(\mathbf{n = 2 5})\end{array}$ & $\begin{array}{c}\text { Group 2 } \\
(\mathbf{n = 2 5 )}\end{array}$ & $\boldsymbol{p}^{*}$ \\
\hline $\begin{array}{l}\text { Age (year) } \\
\text { Gender }\end{array}$ & $58(48-70)$ & $59(36-70)$ & 0.800 \\
$\quad$ Female & $14(56 \%)$ & $16(64 \%)$ & \\
$\quad \begin{array}{l}\text { Male } \\
\text { Body Mass Index }\end{array}$ & $11(44 \%)$ & $9(36 \%)$ & 0.773 \\
$\left(\mathrm{~kg} / \mathrm{m}^{2}\right)$ & $29.59 \pm 4.48$ & $29.83 \pm 3.63$ & 0.691 \\
$\begin{array}{l}\text { Duration of pain } \\
(\text { month) }\end{array}$ & $13.4 \pm 4.07$ & $14.84 \pm 4.96$ & 0.335 \\
Level of disc & & & \\
$\quad$ L4-L5 & $19(76 \%)$ & $20(75 \%)$ & \\
$\quad$ L5-S1 & $6(24 \%)$ & $5(25 \%)$ & 0.735 \\
\hline
\end{tabular}

Data are shown as mean \pm standard deviation, or median (min-max) or number (percent). Group $1=75^{0} \mathrm{C}$ IDET (intradiscal electrothermal therapy), Group $2=90^{\circ} \mathrm{C}$ IDET, * Comparison between groups 
Table 2. Comparison of the M0 and M3, M6, M12, M18 VAS and ODI values of study and control groups.

\begin{tabular}{cccccccc}
\hline & & M0 & M3 & M6 & M12 & M18 & $\boldsymbol{p}^{* * *}$ \\
\hline VAS & Group 1 & $6(3-9)$ & $2(0-6)$ & $2(0-5)$ & $2(0-3)$ & $3(0-7)$ & $<\mathbf{0 . 0 0 1}$ \\
& Group 2 & $6(5-8)$ & $3(0-5)$ & $3(0-4)$ & $2(0-5)$ & $2(0-6)$ & $<\mathbf{0 . 0 0 1}$ \\
& $p^{*}$ & 0.563 & 0.402 & 0.128 & 0.439 & $\mathbf{0 . 0 1 8}$ & \\
ODI & Group 1 & $38(26-50)$ & $24(8-48)$ & $18(6-36)$ & $12(6-20)$ & $12(0-28)$ & $<\mathbf{0 . 0 0 1}$ \\
& Group 2 & $40(32-45)$ & $24(20-38)$ & $19(12-36)$ & $10(6-24)$ & $10(6-24)$ & $<\mathbf{0 . 0 0 1}$ \\
& $p^{*}$ & 0.334 & 0.408 & 0.328 & 0.067 & 0.321 & \\
\hline
\end{tabular}

Data are shown as median (min-max). Group $1=75^{\circ} \mathrm{C}$ IDET (intradiscal electrothermal therapy), Group $2=90^{\circ} \mathrm{C}$ IDET, $\mathrm{VAS}=$ visual analog scale, ODI $=$ Oswestry disability index, M0 = month $0, \mathrm{M} 3=$ month $3, \mathrm{M} 6=$ month 6 , M12= month $12, \mathrm{M} 18=$ month $18,{ }^{*}$ Comparison between groups, $* *$ Comparison within groups (M0 between others)

not enough to warrant the termination of the procedure. None of the patients had permanent or temporal complications. No additional analgesics, PMR, or any other intervention was given to the patients during follow-up.

\section{Discussion}

In the present study, to reduce the risk of thermal injury, we applied IDET by using 2 different catheter tips $\left(75^{\circ} \mathrm{C}\right.$ and $\left.90^{\circ} \mathrm{C}\right)$ and compared the results of $\mathrm{M} 0$, M3, M6, M12, and M18 using the VAS, ODI, and SF36. We reported a statistically significant improvement in both groups at the end of the M12. However, we demonstrated a statistically significant improvement in the VAS and SF-36 pain scores at M18 in patients

Table 3. Comparison of the M0 and M3, M6, M12, M18 SF-36 values of study and control groups.

\begin{tabular}{|c|c|c|c|c|c|c|}
\hline SF-36 & M0 & M3 & M6 & M12 & M18 & $p^{* * *}$ \\
\hline $\begin{array}{l}\text { Physical Function } \\
\text { Group } 1 \\
\text { Group } 2 \\
p^{*}\end{array}$ & $\begin{array}{c}45(35-55) \\
45(35-60) \\
0.334 \\
\end{array}$ & $\begin{array}{c}65(50-80) \\
60(45-75) \\
0.150 \\
\end{array}$ & $\begin{array}{c}70(50-80) \\
60(45-75) \\
0.063 \\
\end{array}$ & $\begin{array}{c}65(45-80) \\
60(45-75) \\
0.145 \\
\end{array}$ & $\begin{array}{c}60(40-75) \\
60(45-80) \\
0.353 \\
\end{array}$ & $\begin{array}{l}<0.001 \\
<0.001\end{array}$ \\
\hline $\begin{array}{l}\text { Physical Role } \\
\text { Group 1 } \\
\text { Group } 2 \\
p^{*} \\
\end{array}$ & $\begin{array}{c}25(10-50) \\
25(12.5-37.5) \\
0.975\end{array}$ & $\begin{array}{c}40(25-55) \\
50(25-75) \\
0.068\end{array}$ & $\begin{array}{c}50(25-75) \\
50(25-75) \\
0.322\end{array}$ & $\begin{array}{c}37.5(12.5-55) \\
37.5(12.5-60) \\
0.387\end{array}$ & $\begin{array}{c}37.5(12.5-60) \\
37.5(12.5-60) \\
0.730\end{array}$ & $\begin{array}{l}<0.001 \\
<0.001\end{array}$ \\
\hline $\begin{array}{l}\text { Pain } \\
\qquad \begin{array}{l}\text { Group 1 } \\
\text { Group 2 } \\
p^{*}\end{array}\end{array}$ & $\begin{array}{c}35(22.5-55) \\
22.5(16.30- \\
70) \\
0.175\end{array}$ & $\begin{array}{c}62(50-70) \\
55(22.5-70) \\
0.421\end{array}$ & $\begin{array}{c}55(35-81) \\
67(22.5-70) \\
0.155\end{array}$ & $\begin{array}{c}45(35-81) \\
35(22.5-70) \\
0.095\end{array}$ & $\begin{array}{c}67(22.5-70) \\
45(22-70) \\
\mathbf{0 . 0 0 3}\end{array}$ & $\begin{array}{l}<0.001 \\
<0.001\end{array}$ \\
\hline $\begin{array}{l}\text { General Health } \\
\text { Group } 1 \\
\text { Group } 2 \\
p^{*}\end{array}$ & $\begin{array}{c}35(20-55) \\
22.5(16.30- \\
70) \\
0.175 \\
\end{array}$ & $\begin{array}{c}65(50-70) \\
60(35-70) \\
0.155\end{array}$ & $\begin{array}{c}60(40-70) \\
65(40-70) \\
0.441\end{array}$ & $\begin{array}{c}60(40-70) \\
60(35-70) \\
0.858\end{array}$ & $\begin{array}{c}50(35-70) \\
60(35-70) \\
0.353\end{array}$ & $\begin{array}{l}<0.001 \\
<0.001\end{array}$ \\
\hline $\begin{array}{l}\text { Vitality } \\
\text { Group 1 } \\
\text { Group 2 } \\
p^{*} \\
\end{array}$ & $\begin{array}{c}35(25-55) \\
35(25-60) \\
0.690 \\
\end{array}$ & $\begin{array}{c}60(25-80) \\
60(50-75) \\
0.192 \\
\end{array}$ & $\begin{array}{c}60(50-80) \\
60(50-75) \\
0.138 \\
\end{array}$ & $\begin{array}{c}65(25-80) \\
65(50-80) \\
0.707 \\
\end{array}$ & $\begin{array}{c}55(50-75) \\
55(25-70) \\
0.920 \\
\end{array}$ & $\begin{array}{l}<0.001 \\
<0.001\end{array}$ \\
\hline $\begin{array}{l}\text { Social Function } \\
\text { Group 1 } \\
\text { Group } 2 \\
p^{*}\end{array}$ & $\begin{array}{c}37.5(25-62.5) \\
37.5(25-50) \\
0.908\end{array}$ & $\begin{array}{c}62.5(25-75) \\
50(25-75) \\
0.309 \\
\end{array}$ & $\begin{array}{c}62.5(25-75) \\
62.5(25-75) \\
0.992 \\
\end{array}$ & $\begin{array}{c}62.5(25-75) \\
50(25-75) \\
0.385 \\
\end{array}$ & $\begin{array}{c}62.5(25-75) \\
50(25-75) \\
0.056\end{array}$ & $\begin{array}{l}<0.001 \\
<0.001\end{array}$ \\
\hline $\begin{array}{c}\text { Emotional Role } \\
\text { Group } 1 \\
\text { Group } 2 \\
p^{*} \\
\end{array}$ & $\begin{array}{c}33(16.3-50) \\
33(16.3-50) \\
0.418 \\
\end{array}$ & $\begin{array}{c}50(16.3-75) \\
33(16.3-50) \\
0.567 \\
\end{array}$ & $\begin{array}{c}50(16.3-75) \\
33(16.3-50) \\
0.406 \\
\end{array}$ & $\begin{array}{c}50(16,3-50) \\
50(16.3-75) \\
0.791 \\
\end{array}$ & $\begin{array}{c}50(16.3-50) \\
50(16.3-50) \\
0.837 \\
\end{array}$ & $\begin{array}{l}<0.001 \\
<0.001\end{array}$ \\
\hline $\begin{array}{l}\text { Mental Health } \\
\text { Group 1 } \\
\text { Group2 } \\
p^{*}\end{array}$ & $\begin{array}{c}44(25-55) \\
35(25-52) \\
0.141\end{array}$ & $\begin{array}{c}62(52-71) \\
60(35-80) \\
0.487\end{array}$ & $\begin{array}{c}62(52-71) \\
60(40-80) \\
0.852\end{array}$ & $\begin{array}{c}62(52-71) \\
55(35-80) \\
0.531\end{array}$ & $\begin{array}{c}55(52-80) \\
60(52-75) \\
0.611\end{array}$ & $\begin{array}{l}<0.001 \\
<0.001\end{array}$ \\
\hline
\end{tabular}

Data are shown as median (min-max). Group $1=75^{\circ} \mathrm{C}$ IDET (intradiscal electrothermal therapy), Group $2=90^{\circ} \mathrm{C}$ IDET, SF$36=$ short form $36, \mathrm{M} 0=$ month $0, \mathrm{M} 3=$ month $3, \mathrm{M} 6=$ month $6, \mathrm{M} 12=$ month $12, \mathrm{M} 18=$ month 18 , * Comparison between groups, ** Comparison within groups (M0 between others) 
who were exposed to $90^{\circ} \mathrm{C}$, compared to those who were exposed to heat temperature of $75^{\circ} \mathrm{C}$.

With the increased use of IDET in patients with CLBP, increased complication rates have been reported in the literature. Manchikanti et al. [17] evaluated complications of 3,500 patients and reported that complications were often associated with technical problems and with heat. Complications associated with heat are cauda equina syndrome due to nerve injury, temporary or permanent long-term low back and leg pain, and vertebral osteonecrosis [17]. The results of this study showed that, unlike seen with the spinal cord, nerve roots and dorsal ganglion were not found in the cerebrospinal fluid (CSF); hence, they were not protected from heat temperatures of more than $45^{\circ} \mathrm{C}$. A meta-analysis analyzing 17 IDET studies demonstrated that this treatment modality was relatively effective and safe with a complication rate of $0.8 \%(0.2$ to $1.4 \%)$ [11]. The insertion of a catheter is also critical in terms of the risk of complications. Konno et al. [18] demonstrated that $70^{\circ} \mathrm{C}$ exposure for five minutes was sufficient to create nerve damage and that there was a possibility of injury, when the catheter was wrongly inserted. In our study, we did not encounter any complications in both groups. This may be due to the fact that our patient count was low or we did not displace the catheter wrongly.

Furthermore, human cadaver studies have investigated the mechanism of the effect of IDET and evaluated its effect on the disc and surrounding tissues [19-21]. In the studies conducted by Wegener et al. [19] in 10 human L4-L5 cadaver vertebral discs, discs with bulging and fissure were excluded. During the measurements of IDET treatment administered to the discs which were considered healthy, the annulus temperature was measured to be $45^{\circ} \mathrm{C}$, although the posterior annulus acted as a heat barrier, and a possibility of thermal injury was considered. However, one of the two risks of the study was the inability of proper insertion of the catheter; the second was the possibility of different heat distributions and variability on damaged discs involved in the study [19]. In another study, heat temperature surrounding the catheter was evaluated and a temperature of $60^{\circ} \mathrm{C}$ to $650 \mathrm{C}$ was obtained, when the catheter was localized at a distance of $2 \mathrm{~mm}$, whereas a temperature of $45^{\circ} \mathrm{C}$ was reported for a distance of 9 to $14 \mathrm{~mm}$ [20]. Kleinstueck et al. [21] including 12 human cadaver specimens demonstrated that a catheter placed at a distance of 1 to $2 \mathrm{~mm}$ could yield collagenous denaturation and reported that the success of treatment could be attributed to other causes. On the other hand, the main limitations of cadaver studies include the lack of the effect of CSF flow and surrounding tissue structures of the platform used for the procedure [1921].

In a study conducted by Derby et al. [22] different procedures of administering IDET were investigated to identify the duration of heating catheter tips at different temperatures during the administration of IDET. A total of 35 patients were evaluated in a treatment procedure involving one or two catheters. Although good results were reported at high temperatures in this retrospective study including 25 patients at eight months, its 16-month follow-up results revealed that the treatment was not effective at high temperatures [22]. The interesting results of our study was, however, the fact that, although the degree of benefit for VAS and SF-36 pain subgroup scores at a catheter tip temperature of $75^{\circ} \mathrm{C}$ which decreased 12 months after treatment, we did not observe any statistically significant difference in the other measurable variables between the two groups.

Furthermore, although favorable conditions prevailed in the group which received a maximum heat temperature of $90^{\circ} \mathrm{C}$, the decline in benefit after 12 months of $75^{\circ} \mathrm{C}$ heating can be attributed to the inability of adequately or permanently maintaining the posterior annulus nerve damage. The affinity of centrifugal growth of the annular nerve fibers was suggested to be due to pain, which also supports our findings [23]. In a study investigating the effect of heat on the nerve tissue, short-term exposure at heat temperatures of $40^{\circ} \mathrm{C}$ to $45^{\circ} \mathrm{C}$ were reported to induce certain damages; however, the damage was reported to be manageable and non-fatal [24]. The physiological effects of the exposures at these temperatures include an increased cellular metabolism, inactivation of enzymes, increased permeability, and increased blood flow [24]. Another factor during recovery was the degree of collagenous shrinking [25]. The catheter tip temperatures used in both groups of our study seem to have attained a degree of providing collagenous shrinking at the nucleus. For this reason, we think that there is no statistically significant difference between the groups in functional recovery in both groups.

\section{The Limitations of the Study}

There are some limitations to this study. Small sample size and retrospective design of the study can be regarded as the limitations. 


\section{Conclusions}

Similar successful results were obtained in our study involving two different heating procedures up to 12 months of administering IDET treatment. But at the 18th month the 900C IDET seems to be more effective in improving the pain scores.

\section{Authorship declaration}

All authors listed meet the authorship criteria according to the latest guidelines of the International Committee of Medical Journal Editors, and all authors are in agreement with the manuscript.

\section{Conflict of interest}

The authors disclosed no conflict of interest during the preparation or publication of this manuscript.

\section{Financing}

The authors disclosed that they did not receive any grant during conduction or writing of this study.

\section{References}

[1] Erdine S. Ağrı .Nobel Medical Publishers, 3rd ed. Istanbul, Nobel Medical Publishers 2007, chapter 52,:427-34.

[2] Schwartzer AC, Aprill CN, Derby R, Fortin J, Kine G, Bogduk N. The prevelance and clinical features of internal disc disruption in patients with chronic low back pain. Spine (Phila Pa 1976) 1995;20:1878-83.

[3] Freedman BA, Cohen SP, Kuklo TR, Lehman RA, Larkin P, Giuliani JR. Intradiscal electrothermal therapy (IDET) for chronic low back pain in active-duty soldiers: 2-year follow-up. Spine J 2003;3:502-9.

[4] Ren L, Guo H, Zhang T, Han Z, Zhang L, Zeng Y. Efficacy evaluation of percutaneous laser disc decompression in the treatment of lumbar disc herniation. Photomed Laser Surg 2013;31:174-8.

[5] Fukui S, Nitta K, Iwashita N, Tomie H, Nosaka S, Rohof O. Intradiscal pulsed radiofrequency for chronic lumbar discogenic low back pain Intradiscal: a one year prospective outcome study using discoblock for diagnosis. Pain Physician 2013;16:E435-42.

[6] Saal JA, Saal JS, Ashley J. Targeted intradiscal thermal therapy: preliminary feasibility results; Presented at the anual meeting of the international society for the study of the lumbar spine; June 2-6, 1997; Singapore.

[7] Saal JS, Saal JA. Management of chronic discogenic low back pain with a thermal intradiscal catheter. A preliminary report. Spine (Phila Pa 1976) 2000;25:382-8.

[8] Saal JA, Saal JS. Intradiscal electrothermal treatment for chronic discogenic low back pain. A prospective outcome study with a minimum 1-year follow-up. Spine (Phila Pa 1976) 2000;25:2622-7.

[9] Assietti R, Morosi M, Migliaccio G, Meani L, Block JE. Treatment of discogenic low back pain with Intradiscal Electrothermal Therapy (IDET): 24 months follow-up in 50 consecutive patients. Acta Neurochir Suppl 2011;108:103-5.

[10] Andersson GB, Mekhail NA, Block JE. Treatment of intractable discogenic low back pain. A systematic review of spinal fusion and IDET. Pain Physician. 2006;9:237-48.

[11] Appleby D, Andersson G, Totta M. Meta-analysis of the efficacy and safety of intradiscal electrothermal therapy (IDET). Pain Med 2006; 7:308-16.

[12] Ackerman WE. Cauda eguina syndrome after intradiscal electrothermal therapy. Reg Anaesth Pain Med 2002;27:622.

[13] Scholl BM, Theiss SM, Lopez-Ben R, Kraft M. Vertebral osteonecrosis related to intradiscal electrothermal therapy. A case report. Spine (Phila Pa 1976) 2003;28:E161-4.

[14] Huskisson EC. Measurement of pain. Lancet 1974;2:1127-31.

[15] Yakut E, Düger T, Oksüz C, Yörükan S, Ureten K, Turan D, et al. Validation of the Turkish version of the Oswestry Disability Index for patients with low back pain. Spine (Phila Pa 1976) 2004;29:581-5.

[16] Koçyiğit H, Aydemir Ö, Fişek G, Ölmez N, Memiş A. Kısa Form36'nın Türkçe Versiyonunun Güvenilirliği ve Geçerliliği. İlaç ve Tedavi Dergisi 1999;12:102-6.

[17] Manchikanti L, Datta S, Derby R, Helm S. Intradiscal electrothermal therapy treatment for back pain. Pain Manag 2011;1:4151.

[18] Konno S, Olmarker K, Byrod G, Nordborg C, Strömqvist B, Rydevik B. The European Spine Society AcroMed Prize 1994. Acute thermal nerve root injury. Eur Spine J 1994;3:299-302.

[19] Wegener B, Rieskamp K, Büttner A, Habiyambere V, von SchultzePellangahr C, Schaffer V, et al. Experimental evaluation of the risk of extradiscal thermal damage in intradiscal electrothermal therapy (IDET). Pain Physician 2012;15:E99-E106.

[20] Bono CM, Iki K, Jalota A, Dawson K, Garfin SR. Temperatures within the lumbar disc and endplates during intradiscal electrothermal therapy: formulation of a predictive temperature map in relation to distance from the catheter. Spine (Phila Pa 1976) 2004; 29:1124-9; discussion 1130-1.

[21] Kleinstueck FS, Diederich CJ, Nau WH, Puttlitz CM, Smith JA, Bradford DS, et al. Temperature and thermal dose distributions during intradiscal electrothermal therapy in the cadaveric lumbar spine. Spine (Phila Pa 1976) 2003;28:1700-8.

[22] Derby R, Seo KS, Kazala K, Chen YC, Lee SH, Kim BJ. A factor analysis of lumbar intradiscal electrothermal annuloplasty outcomes. Spine J 2005;5:256-61.

[23] Coppes MH, Marani E, Thomeer RT, Groen GJ. Innervation of "painful" lumbar discs. Spine (Phila Pa 1976) 1997;22: 2342-50.

[24] Engin K. Biological rationale and clinical experience with hyperthermia. Control Clin Trials 1996;17:316-42.

[25] Bogduk N, Lau P, Govind J, Karasek M. Intradiscal electrothermal therapy. Tech Reg Anesth Pain Manage 2005;9:25-34. 